\title{
Ultralow Level Mercury Treatment Using Chemical Reduction and Air Stripping: Scoping Report
}

by

B. B. Looney

Westinghouse Savannah River Company

Savannah River Site

Aiken, South Carolina 29808

M. E. Denham

K. M. Vangelas

J. W. Koch

DOE Contract No. DE-AC09-96SR18500

This paper was prepared in connection with work done under the above contract number with the U.S.

Department of Energy. By acceptance of this paper, the publisher and/or recipient acknowledges the U.S.

Government's right to retain a nonexclusive, royalty-free license in and to any copyright covering this paper, along with the right to reproduce and to authorize others to reproduce all or part of the copyrighted paper. 


\section{Ultralow Level Mercury Treatment Using Chemical Reduction and Air Stripping: Scoping Report}

Westinghouse Savannah River Company

Savannah River Site

Aiken, South Carolina 29808

Prepared for the United States Department of Energy under Contract No. DE-AC09-96-SR18500 


\section{DISCLAIMER}

This report was prepared as an account of work sponsored by an agency of the United States Government. Neither the United States Government nor any agency thereof, nor any of their employees, makes any warranty, express or implied, or assumes any legal liability or responsibility for the accuracy, completeness, or usefulness of any information, apparatus, product or process disclosed, or represents that its use would not infringe privately owned rights. Reference herein to any specific commercial product, process or service by trade name, trademark, manufacturer, or otherwise does not necessarily constitute or imply its endorsement, recommendation, or favoring by the United States Government or any agency thereof. The views and opinions of authors expressed herein do not necessarily state or reflect those of the United States Government or any agency thereof.

This report has been reproduced directly from the best available copy.

Available for sale to the public, in paper, from: U.S. Department of Commerce, National Technical Information Service, 5285 Port Royal Road, Springfield, VA 22161, phone: (800) 553-6847

fax: (703) 605-6900

email: orders@ntis.fedworld.gov

online ordering: http://www.ntis.gov/ordering.htm

Available electronically at http://www.doe.gov/bridge

Available for a processing fee to U.S. Department of Energy and its contractors, in paper, from: U.S. Department of Energy, Office of Scientific and Technical Information, P.O. Box 62, Oak Ridge, TN 37831-0062, phone: (865) 576-8401

fax: (865) 576-5728

email: reports@adonis.osti.gov

\section{Acknowledgements}

The authors gratefully acknowledge the support of the U.S. Department of Energy, the Savannah River Technology Center and the operating divisions of the Savannah River Site who support the Strategic Research and Development Program. We also recognize the early work of George Southworth (Oak Ridge National Laboratory). We are extending the results of his early studies and appreciate his gracious support and guidance. We also acknowledge the contributions of Nicholas Bloom (Frontier Geosciences) who has provided valuable guidance on performing ultralow level mercury work of this type and who has provided a very high quality support to SRTC under our subcontract. Finally, we acknowledge the excellent support of the SRTC glassblowers and laboratory technicians. 


\section{DISCLAIMER}

Portions of this document may be illegible in electronic image products. Images are produced from the best available original document. 
Ultralow Level Mercury Treatment Using Chemical Reduction and Air Stripping: Scoping Report

\author{
B. B. Looney \\ M. E. Denham \\ K. M. Vangelas \\ J. W. Koch
}

Environmental Science and Technology

Savannah River Technology Center

31 July 2000

Westinghouse Savannah River Company

Savannah River Site

Aiken, South Carolina 29808

Prepared for the United States Department of Energy under Contract No. DE-AC09-96-SR18500 
UItralow Level Mercury Treatment Using Chemical Reduction and Air Stripping: Scoping Report

\section{Table of Contents}

$\begin{array}{lc}\text { Abstract } & \\ \text { Objectives } & 1 \\ \text { Background } & 1 \\ \text { Summary Description of Research } & 2 \\ \text { Technical Approach } & 3 \\ \text { Mercury Chemistry } & \\ \text { Selection of Water for Stage 1 Tests } & 3 \\ \text { Equipment } & 5 \\ \text { General Protocol } & 6 \\ \text { Analytical } & 8 \\ \text { Results } & 11 \\ \text { Scoping Analysis } & 12 \\ \text { Summary and Future Plans } & 13 \\ \text { References } & 14\end{array}$

Appendix 1-Dosing Protocols $\quad 15$

Appensix 2 - Tabulated Analytical Results 17 


\section{Ultralow Level Mercury Treatment Using Chemical Reduction and Air Stripping: Scoping Report}

\section{List of Tables}

1. Half-cell reactions for tin, mercury, and potential interferences.

\section{List of Figures}

1. Relation between the $\mathrm{Sn}(\mathrm{m}) / \mathrm{Sn}(\mathrm{IV})$ redox couple and mercury speciation. $\quad 4$

2a. Overall schematic of system 6

2b. Detail of bottle/reactor design $\quad 7$

3. Experimental apparatus set up in the field near the A-Area Stripper 8

4. Photograph of (A) gas delivery system and (B) operating sparge vessel 9

5. Miscellaneous photographs of SRTC researchers performing study 10

6. Collection of sample for a kinetic study of mercury-tin reaction rates 11

7. Mercury Treatment Results for SRS samples 12 


\title{
Ultralow Level Mercury Treatment Using Chemical Reduction and Air Stripping: Scoping Report
}

\begin{abstract}
Data collected during the first stage of a Savannah River Technology Center (SRTC) Strategic Research and Development Project confirmed the efficacy of chemical reduction and air stripping/sparging as an ultralow level mercury treatment concept for waters containing $\mathrm{Hg}$ (II). The process consists of dosing the water with low levels of stannous chloride to convert the mercury to $\mathrm{Hg}^{\circ}$. This form of mercury can easily be removed from the water by air stripping or sparging. Samples of Savannah River Site (SRS) groundwater containing approximately $130 \mathrm{ng} / \mathrm{L}$ of total mercury (as $\mathrm{Hg}$ (II)) were used for the study. In undosed samples, sparging removed $0 \%$ of the initial mercury. In the dosed samples, all of the removals were $>94 \%$, except in one water type at one dose. This sample, which was saturated with dissolved oxygen, showed a $63 \%$ reduction in mercury following treatment at the lowest dose. Following dosing at minimally effective levels and sparging, treated water contained less than $10 \mathrm{ng} / \mathrm{L}$ total mercury. In general, the data indicate that the reduction of mercury is highly favored and that stannous chloride reagent efficiently targets the $\mathrm{Hg}(\mathrm{II})$ contaminant in the presence of competing reactions. Based on the results, we estimated that the costs of implementing and operating an ultralow level mercury treatment process based on chemical reduction and stripping/sparging are $10 \%$ to $20 \%$ of traditional treatment technologies.
\end{abstract}




\section{Ultralow Level Mercury Treatment Using Chemical Reduction and Air Stripping: Scoping Report}

\section{Objectives}

The overall objective of this work is to develop a reasonable and cost-effective approach to meet the emerging mercury standards, especially for high volume outfalls with concentrations below the drinking water standard (DWS). The specific objectives of the various tasks are to determine the efficacy and practicality of treating aqueous mercury to $\mathrm{ng} / \mathrm{L}$ levels using a combination of chemical reduction (to $\mathrm{Hg}^{0}$ ) followed by stripping/sparging.

\section{Background:}

Over the past ten years the Environmental Protection Agency (EPA) has developed a policy aimed at elimination of mercury emissions. This policy has been articulated in the PBT (Persistent, Bioaccumulative and Toxic) Pollutants Program, the White House Clean Water Action Plan, the Mercury Report to Congress, the executive order for federal agency assessments of risks to children, and the U.S.-Canada Bilateral Toxics Agreement. In each case, mercury was identified as the most significant contaminant and specific actions to reduce and/or eliminate mercury were required. Proposed ecological protection mercury standards are well below drinking water standards and are so low that new analytical methods have been developed and were approved in 1999 (EPA method 1631). Carol Browner of the EPA recently announced a plan to eliminate dilution from mixing calculations in permitting National Pollutant Discharge Elimination System (NPDES) outfalls, primarily to meet mercury commitments made in the US-Canada Bilateral Toxics Agreement. A policy of regulating mercury to ultralow levels may affect many outfalls at SRS and will impact industry, municipalities and other government agencies. New water treatment approaches are needed. To be viable, these approaches must treat large volumes of water containing trace levels of mercury in the presence of other ions at a unit cost that is below conventional metals removal methods.

In South Carolina, the Department of Health and Environmental Control (SCDHEC) has indicated that future discharge permits will be based on ambient water quality criteria (AWQC). The current AWQC is $12 \mathrm{ng} / \mathrm{L} \mathrm{--}$ a level that is near background concentration, approximately one tenth of traditional detection limits, and approximately one hundredth of DWS. Draft surface water protection standards (e.g., those currently proposed by EPA for Total Daily Maximum Load (TMDL) in the Savannah River) are even lower $-1 \mathrm{ng} / \mathrm{L}$. A challenge for large facilities such as the Savannah River Site (SRS) is developing reasonable and cost-effective approaches to meet the emerging standards, especially for high volume outfalls with concentrations below the DWS (currently $2000 \mathrm{ng} / \mathrm{L}$ ). The mercury issue has already adversely impacted negotiations 
and plans for the A-01 Outfall that receives water from the Savannah River Technology Center (SRTC) and the Environmental Restoration Division (ER).

SRS has formed a task team to identify traditional commercial treatment options for metals. Unfortunately, traditional treatments cost more than $\$ 2 / \mathrm{m}^{3}$ ( $\$ 10$ per 1000 gallons). This is equivalent to a cost of more than $\$ 2,000,000 /$ year for a $2 \mathrm{~m}^{3} / \mathrm{min}$ (400 gpm) outfall. We are examining an alternative treatment method. This approach is a modification of analytical methods for mercury in which stannous chloride is used to rapidly convert inorganic mercury into volatile-dissolved metallic mercury for removal by air stripping. Such a system consists of a reagent infusion pump (or system), a mixing zone, and an air-water contactor (e.g., stripper). If successful, the system would be widely applicable because it would cost much less than traditional water treatment methods.

Analytical methods typically employ a large stoichiometric excess of stannous ion but the literature hints that lesser quantities are sufficient. Development of this treatment system requires answering a few key scientific questions (stoichiometry, robustness, etc.) and assembling a prototype to show that reliable long-term operation can be achieved. These research questions and objectives are listed and discussed below.

\section{Summary Description of Research}

The basis for this project is the chemistry embodied in various analytical methods for mercury. In these methods, inorganic mercury is reduced to $\mathrm{Hg}^{0}$ using stannous (tin) chloride. $\mathrm{Hg}^{0}$ is volatile and can be removed from the water by simple air-water contact. In the lab, a small sparge is used to strip the mercury into an analyzer. For treatment, air stripping, spraying, or sparging are examples of inexpensive methods applicable to large water volumes. The reaction of tin and inorganic mercury is rapid and thermodynamically favored. Nonetheless, tin-based analytical methods rely on using significant excess reagent to assure that the reaction is complete. Research by George Southworth (Y/ER-277, ORNL) provides a hint that tin levels that are only 4 to 5 times stoichiometry may convert the available inorganic mercury to $\mathrm{Hg}^{0}$. This stoichiometry, under one particular-set of water chemistry conditions, suggests that the mercury-tin reaction is relatively specific. These ratios also indicate that treatment is possible using tin concentrations that are well within safe-protective levels for both ecological and human health. Further, the research documented that the strippability of the resulting $\mathrm{Hg}^{0}$ is predictable and that required air-water ratios are favorable (e.g., ratios less than 20 provide good removal). The proposed work will attempt to prove the concept and support practical application.

Our data will support development of a predictable treatment method based on this literature and build and test a scaled up model. This research will be conducted in two stages: (1) Scoping Studies and (2) Proof of Principle. This report documents the successful completion and results of the Scoping Studies Stage.

The Scoping Studies were performed using "real-world" water collected from groundwater wells. We selected this water, with a nominal concentration near $150 \mathrm{ng} / \mathrm{L}$, 
to represent a potential SRS treatment need. We treated the water with a range of stannous chloride concentrations. We sparged each sample using ultraclean equipment and an excess air-water ratio of approximately 30 to 1 . The resulting samples were sealed and sent for total mercury analysis in the laboratory using cold vapor atomic fluorescence spectrometry. We collected a large $5 \mathrm{~L}$ sample for a kinetic study to further examine the reaction and mixing times needed. These results will be reported during Stage 2. Work was performed in accordance with the original test plan (Vangelas, 2000) and is documented in a project specific laboratory notebook (Looney, 2000). Based on the results of the Scoping Studies, we will assemble a prototype treatment system during Stage 2. The objective of the Proof of Principle system will be to test design simplicity and robustness. This system will be used to determine reagent stability and if required concentrations and flows can be reliably maintained.

\section{Technical Approach}

\section{Mercury Chemistry}

The chemistry of mercury in the environment is complicated by multiple redox states, a tendency to form complex ions, and potential biological transformations. Mercury can exist naturally as the elemental form (zero valent), a univalent form [ $\mathrm{Hg}(\mathrm{I})]$, and a divalent form $[\mathrm{Hg}(\mathrm{II})]$. The univalent form occurs predominantly in solid phases such as calomel $\left(\mathrm{Hg}_{2} \mathrm{Cl}_{2}\right)$, but typically dissociates into the elemental and divalent forms when in solution. $\mathrm{Hg}(\mathrm{II})$ has a strong tendency to form complex ions with hydroxyls, chloride, and other common anions. The relative stability of these complexes varies with parameters such as $\mathrm{pH}$ and thus, understanding the chemistry of the solution is important to remediation design. Under moderately reducing conditions $\mathrm{Hg}(\mathrm{II})$ can be converted to elemental mercury. In this redox state mercury can co-exist as liquid metal, vapor, and aqueous solute. Under more reducing conditions where sufficient organic matter is present, microbiological transformations of mercury to methylated forms can occur. These species are the most toxic forms of mercury and are mobile in the environment. However, most groundwater at the Savannah River Site contains very little, if any, methylated mercury (Denham et al, 1999).

Figure 1 shows the relationship between the $\operatorname{Sn}(\mathrm{II}) / \mathrm{Sn}(\mathrm{IV})$ couple and the speciation of mercury in aqueous solution. In highly oxidized natural waters (above a $\mathrm{pE}$ of approximately 8), mercury occurs as $\mathrm{Hg}(\mathrm{II})$, typically as a chloride or hydroxide complex. That the equal activity line of the $\operatorname{Sn}(\mathrm{II}) / \mathrm{Sn}(\mathrm{IV})$ couple is located within the field of dominance of elemental mercury indicates that $\mathrm{Sn}(\mathrm{II})$ will reduce $\mathrm{Hg}$ (II) to elemental mercury. This occurs by the following reaction:

$\mathrm{HgCl}_{2}{ }^{\circ}+\mathrm{Sn}^{+2}=\mathrm{Hg}^{\circ}+2 \mathrm{Cl}^{-}+\mathrm{Sn}^{+4}$

Thus, when sufficient stannous chloride is added to water containing dissolved $\mathrm{Hg}$ (II) virtually all $\mathrm{Hg}(\mathrm{II})$ is reduced to elemental mercury. Importantly, mercury occurs primarily as $\mathrm{Hg}(\mathrm{I})$, and its complexes, in most natural waters, even water where $\mathrm{Hg}^{\circ}$ is 
thermodynamically predicted (e.g., $\mathrm{pE}<8$ ). In these systems, the reaction with tin facilitates the transformation of the $\mathrm{Hg}(\mathrm{II})$ to the expected zero valence oxidation state. In all cases, the stannous ion must be added in sufficient quantity that a $1: 1 \mathrm{Hg}: \mathrm{Sn}$ stoichiometry is available in the presence of competing redox reactions.

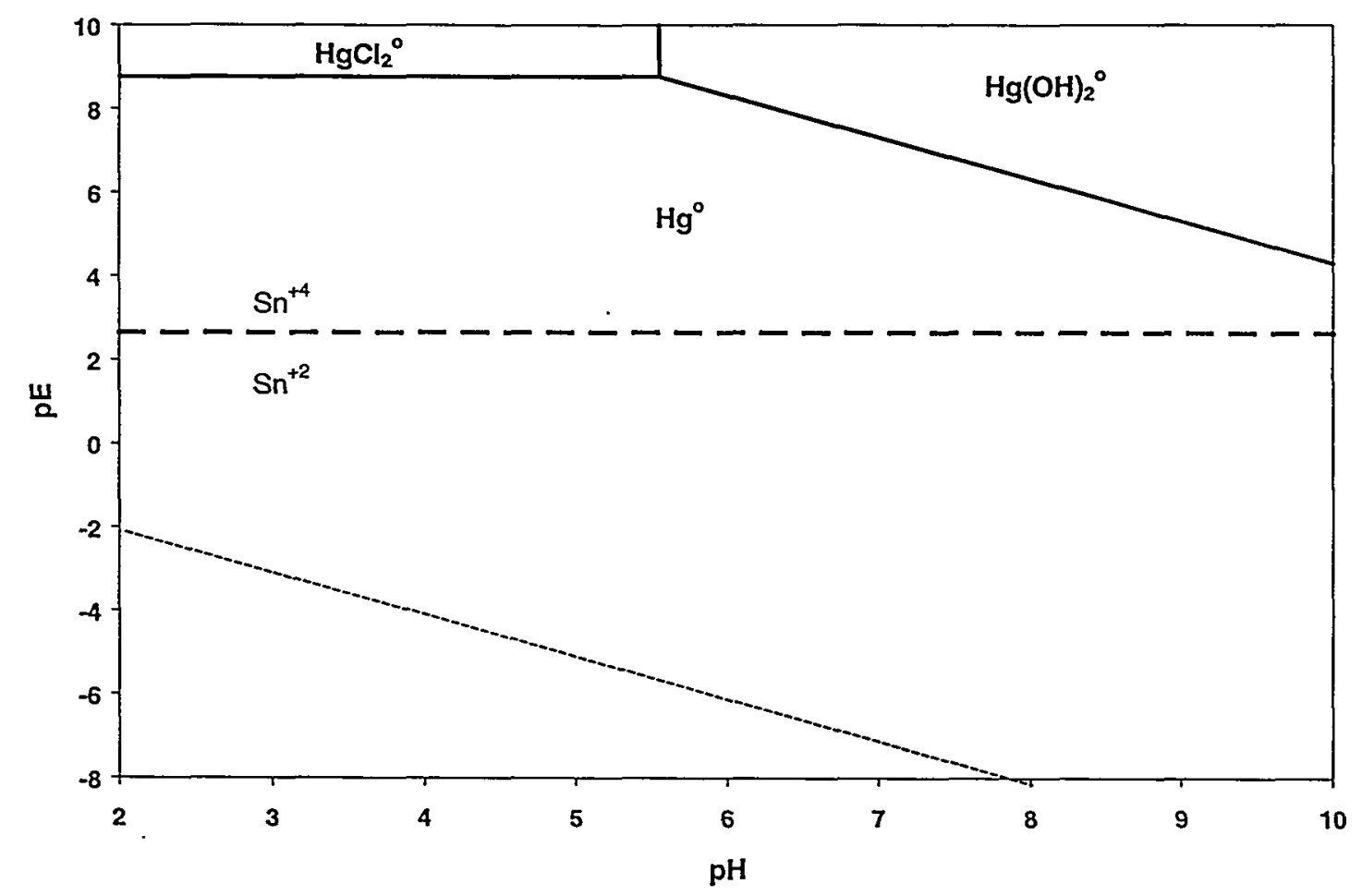

Figure 1: Relation between the $S n(I I) / S n(I V)$ redox couple and mercury speciation. $[C I]=2 \mathrm{mg} / \mathrm{L}$. The coarse dashed line shows the boundary between $\mathrm{Sn}(\mathrm{II})$ and $\mathrm{Sn}(\mathrm{IV})$ fields of dominance. The fine dashed line represents the lower stability limit of water.

The remediation technology being tested exploits the redox chemistry of mercury and the relatively high vapor pressure of elemental mercury. Stannous chloride $\left(\mathrm{SnCl}_{2}\right)$ is used to reduce dissolved divalent mercury to elemental mercury. The dissolved elemental mercury is then stripped from solution by air sparging. Stannous chloride will also reduce other dissolved constituents such as oxygen, nitrate, and contaminants such as trichloroethylene (TCE). Table 1 shows the Standard Potential of the $\mathrm{Sn}(\mathrm{IV}) / \mathrm{Sn}(\mathrm{I})$ halfcell reaction relative to the mercury couple and to other potential interfering constituents. Oxygen and nitrate are typically present in groundwater at concentrations that are much greater than concentrations of mercury. Likewise, in groundwater contaminated with TCE, mercury concentrations may be small compared to TCE concentrations. The high concentrations of these constituents relative to mercury may require use of a higher concentration of stannous chloride than needed for stoichiometric reduction of mercury. 
Table 1: Half-cell reactions for tin, mercury, and potential interferences. Standard Potentials are in volts vs. the Standard Hydrogen Electrode (SHE).

\begin{tabular}{|l|l|}
\hline Half-cell Reaction & Standard Potential vs. SHE (volts) \\
\hline $\mathrm{Sn}^{+4}+2 \mathrm{e}^{-}=\mathrm{Sn}^{+2}$ & 0.16 \\
\hline $\mathrm{C}_{2} \mathrm{HCl}_{3(\mathrm{TCE})}+\mathrm{H}^{+}+2 \mathrm{e}^{-}=\mathrm{C}_{2} \mathrm{H}_{2} \mathrm{Cl}_{2(1,1-\mathrm{DCE})}+\mathrm{Cl}^{-}$ & 0.54 \\
\hline $\mathrm{NO}_{3}^{-}+2 \mathrm{H}^{+}+2 \mathrm{e}^{-}=\mathrm{NO}_{2}^{-}+\mathrm{H}_{2} \mathrm{O}$ & 0.83 \\
\hline $\mathrm{Hg}^{+2}+2 \mathrm{e}^{-}=\mathrm{Hg}$ & 0.85 \\
\hline $\mathrm{O}_{2(\mathrm{a})}+4 \mathrm{H}^{+}+4 \mathrm{e}^{-}=2 \mathrm{H}_{2} \mathrm{O}$ & 1.27 \\
\hline
\end{tabular}

\section{Selection of Water for Stage 1 Tests}

We used "real-world" samples for the stage 1 tests. In selecting the source of contaminated water, we reviewed outfalls and wells at SRS. The primary criteria for the selection were:

1) concentrations of mercury should be well characterized and stable,

2) concentrations of mercury should be elevated above background but less than DWS,

3) water from the selected source should be accessible for sampling and study,

4) mercury in the water should be primarily in the form of $\mathrm{Hg}(\mathrm{II})$, and

5) if possible, the water should discharge to a surface water outfall and represent a possible future treatment target.

Based on these criteria, we selected the influent and effluent of the A-Area stripper for the work. The source of the water is groundwater remediation wells located in the northern sector of A/M Area near SRTC. The feed and effluent of the air stripper have been well characterized and provide a very stable source of water that contains between approximately 120 and $150 \mathrm{ng} / \mathrm{L}$ total mercury -- concentrations that are ideal for the scoping study. Previous speciation studies on these waters indicated that almost all of the mercury is $\mathrm{Hg}(\mathrm{I})$. Interestingly, since an air stripper is already in place, the measured concentrations indicate that mercury is not being removed by this unit operation without the benefit of reagent addition. The use of both feed and effluent water provides an interesting comparison of stannous chloride effectiveness in the presence of varying competing reactions (the feed contains significant levels of chlorinated organic solvents and the feed and effluent both contain dissolved oxygen). Finally, a run was performed on A-Area Stripper feed water that was pre-sparged with nitrogen to remove both dissolved oxygen and volatile organic compounds to evaluate the optimum theoretical performance of the treatment method. The effluent from the A-Area Stripper discharges to the A-01 Outfall and represents a significant fraction of the outfall flow volume. Thus, the stripper represents a potential treatment target if ultralow level outfall standards are promulgated. 


\section{Equipment}

Figures $2 \mathrm{a}$ and $2 \mathrm{~b}$ are drawings of the equipment setup used for this study. The ultra-low levels of mercury in the samples required using materials that do not contain mercury and will not absorb mercury from their surroundings. Furthermore, to be compatible with EPA cleaning protocol, equipment materials should be stable in hot $\left(70^{\circ} \mathrm{C}\right)$ hydrochloric acid. The majority of the equipment was composed of glass, teflon, polypropylene or polyvinylidene difluoride (PVDF) which meet these various requirements. In general, the project will utilize nonmetallic components when possible.

We performed all sample preparation and manipulation inside a field glovebox. We used the glovebox to minimize the possibility of contaminating the samples from outside sources and to protect the reagents from the air.

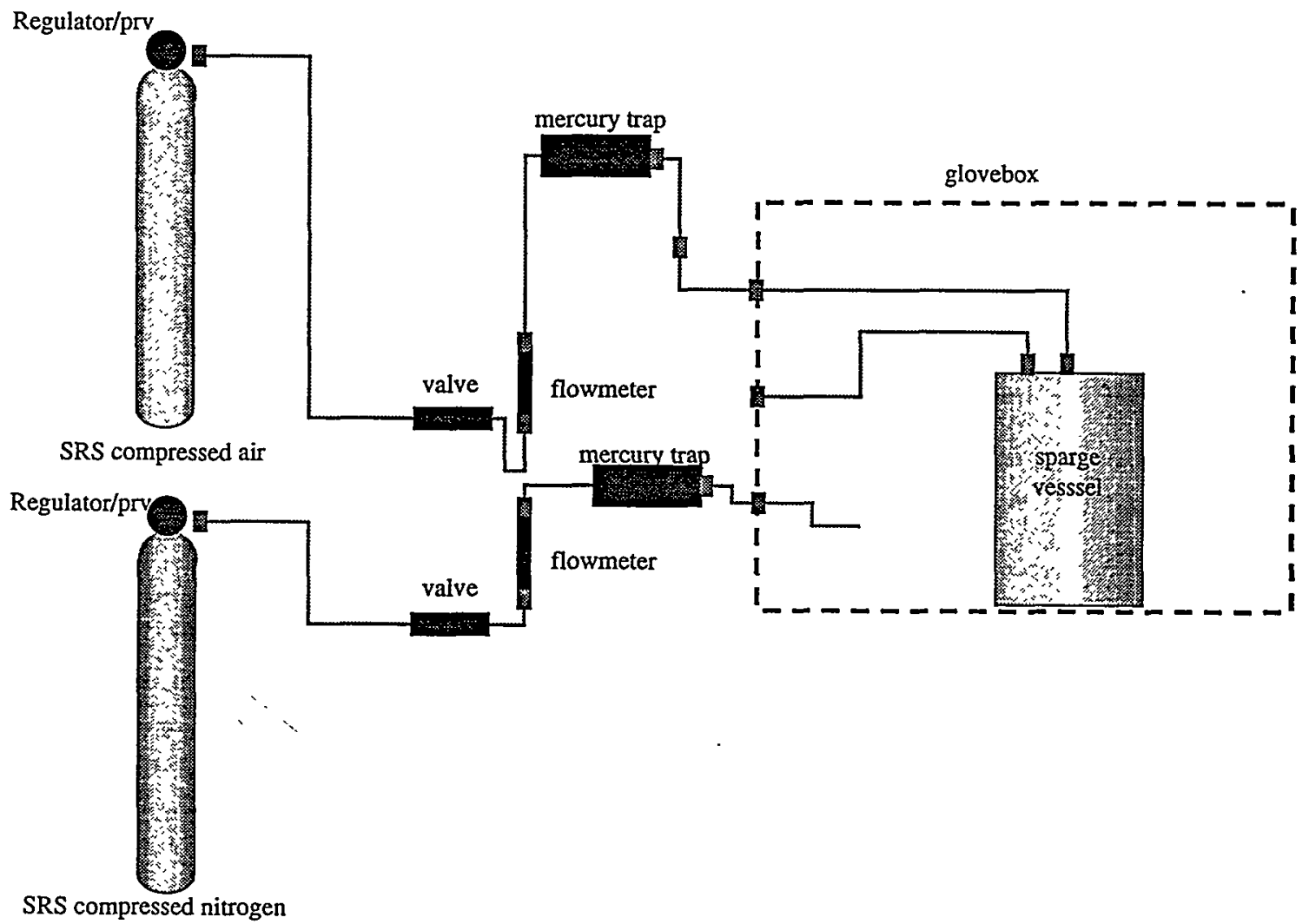

Figure $2 a$. Overall schematic of system 


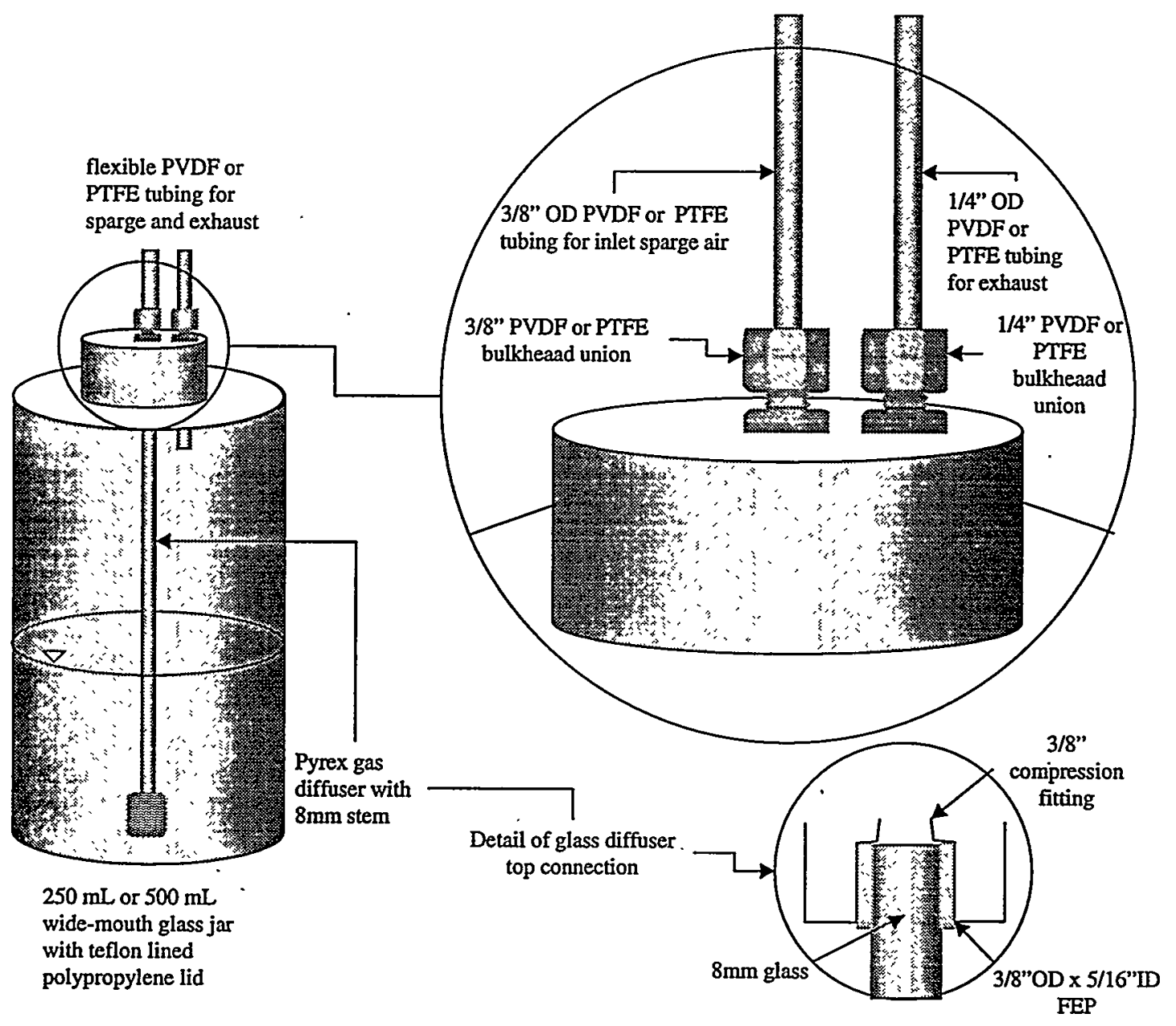

Figure 2b. Detail of bottle/reactor design 


\section{General Protocol}

The Stage 1 experiments evaluated the response of mercury concentration in a treated sample to the stannous chloride dosage. A blank run was performed on every cleaned sparge vessel as a QA step. This blank run was followed by an experimental run that tested stannous chloride dosages from 0 to approximately $800 \mathrm{mg} / \mathrm{L}$. The actual doses are shown in Appendix A. The protocol allowed study of doses at practical engineering levels and extended up to the actual high dosages used in the 1631 analytical method. All work was performed in the field in a glove box set up near the A-Area Stripper. Figures 3 through 5 are photographs of the field operations.
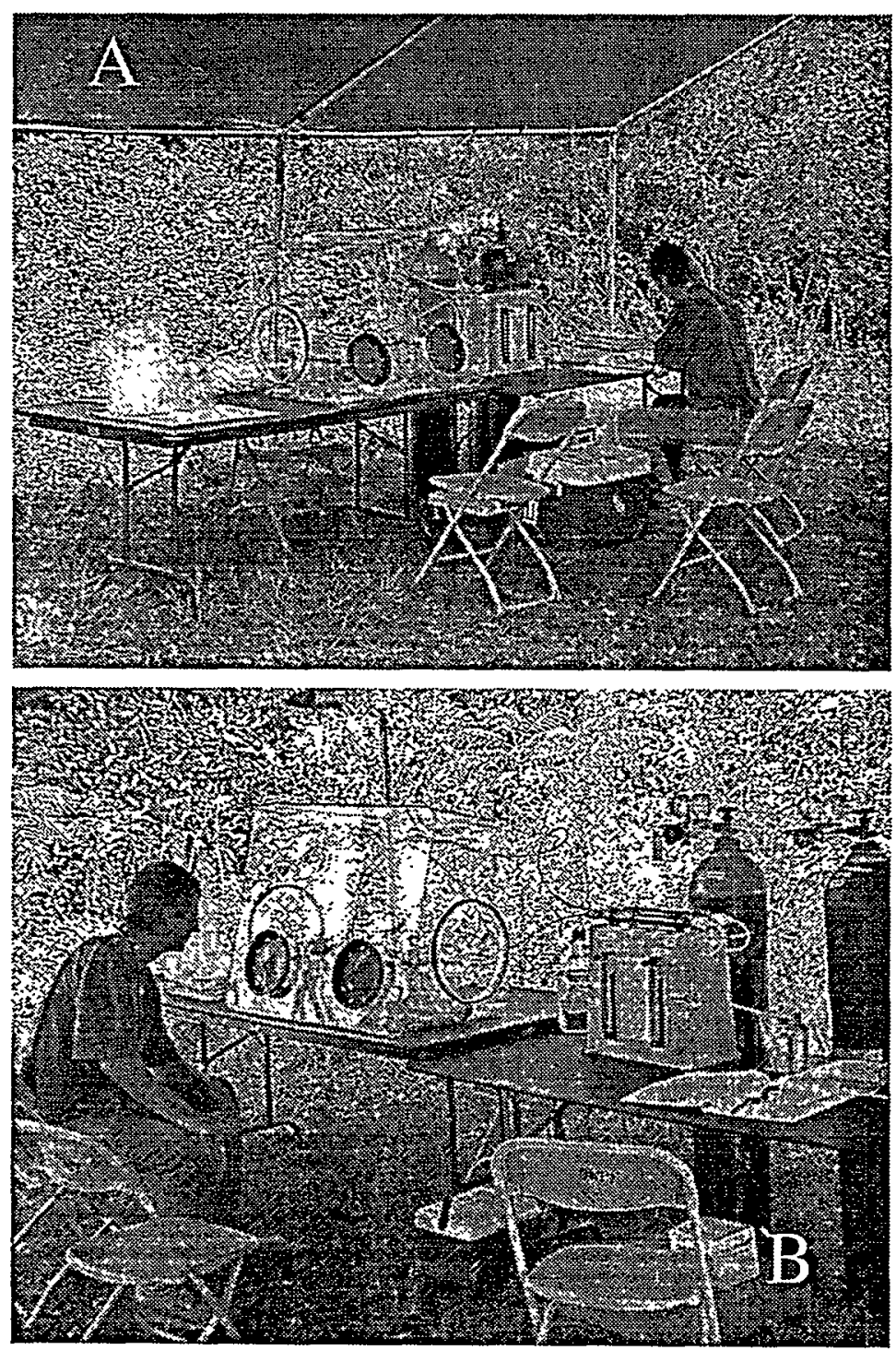

Figure 3: Experimental apparatus set up in the field near the A-Area Stripper. Photographs show (A) general set up and $(B)$ arrangement of glovebox and support equipment 

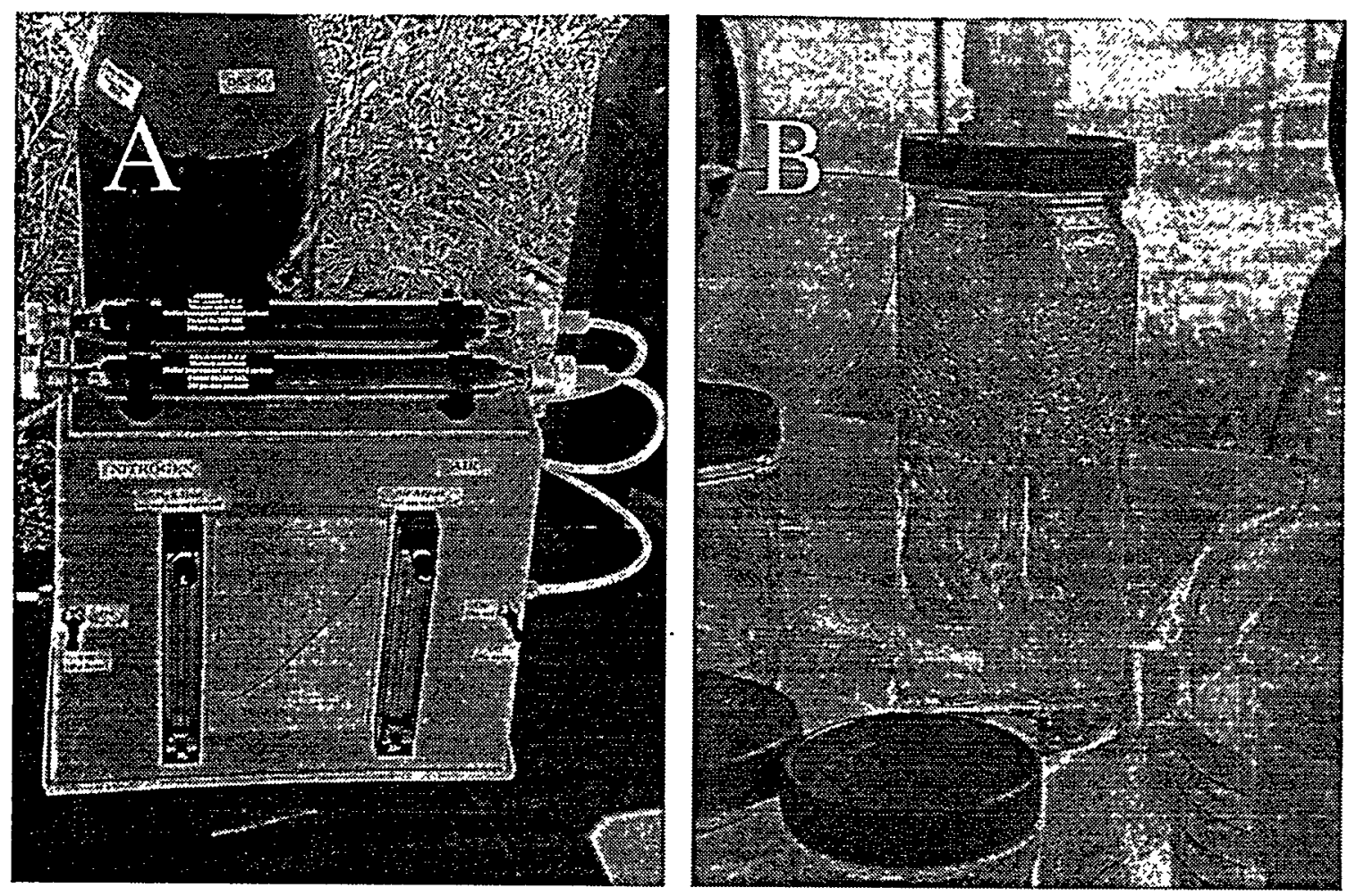

Figure 4: Photograph of $(A)$ gas delivery system and $(B)$ operating sparge vessel 


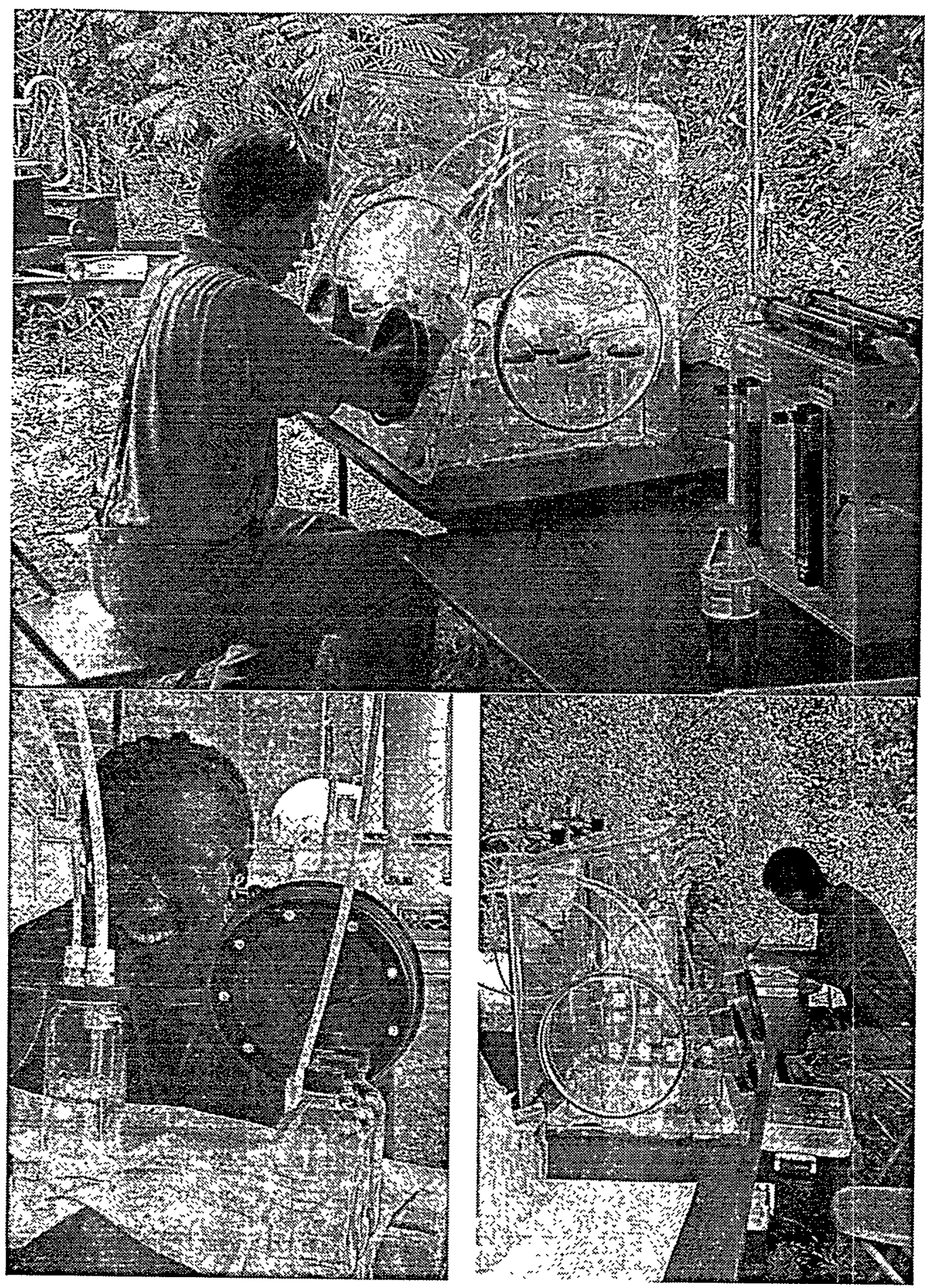

Figure 5: Miscellaneous photographs of SRTC researchers performing study 
EPA method 1631 was used for analysis of samples for this work. A recognized and experienced ultralow level mercury analysis laboratory (Frontier Geosciences, Seattle WA) was chosen to support this research. Nicholas Bloom of Frontier Geosciences was a principal contributor to the development of EPA Method 1631. He and his staff provided sample containers, bottle cleaning, quality assurance and other support under a subcontract to SRTC. Frontier will also perform a kinetic experiment in their laboratory with SRS water to help determine reaction rates and to help resolve long-term engineering issues. Figure 6 shows collection of a 5L sample in a precleaned teflon container for the kinetic study. All of the analytical results are tabulated in Appendix 2.

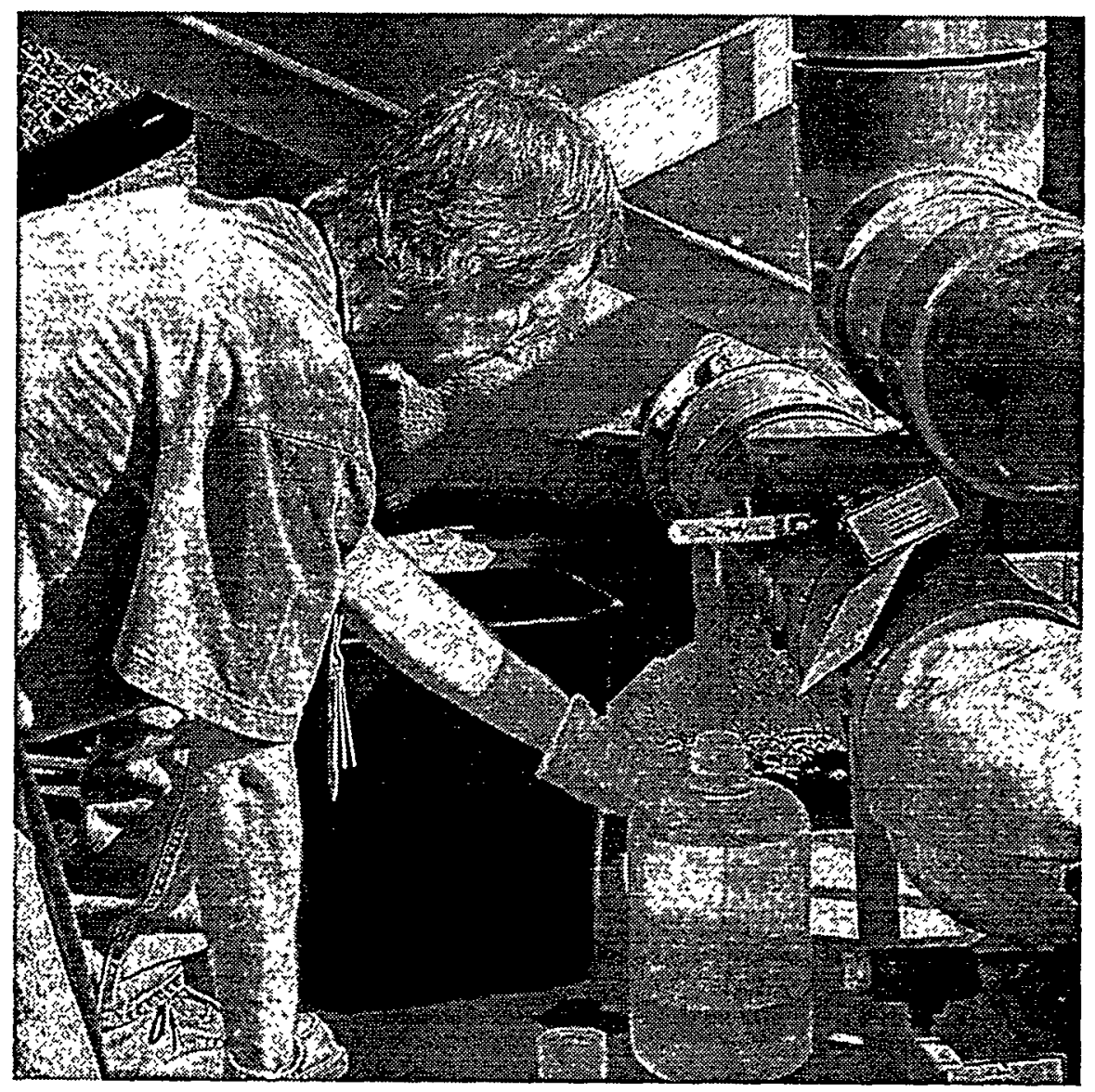

Figure 6: SRTC researcher Miles Denham collects large volume sample for a kinetic study of mercury-tin reaction rates. These results will be reported during the proof-ofprinciple stage of the project. 


\section{Results}

The mercury treatment was extremely efficient. In the feed water run and nitrogen sparged effluent water run, the mercury concentrations in the treated water were below 10 $\mathrm{ng} / \mathrm{L}$ for all doses. In the raw effluent water run, mercury concentrations in the treated water were below $10 \mathrm{ng} / \mathrm{L}$ in for all but the lowest stannous chloride dose. These results are shown on Figure 7.

Stannous Chloride Mercury Treatment Results

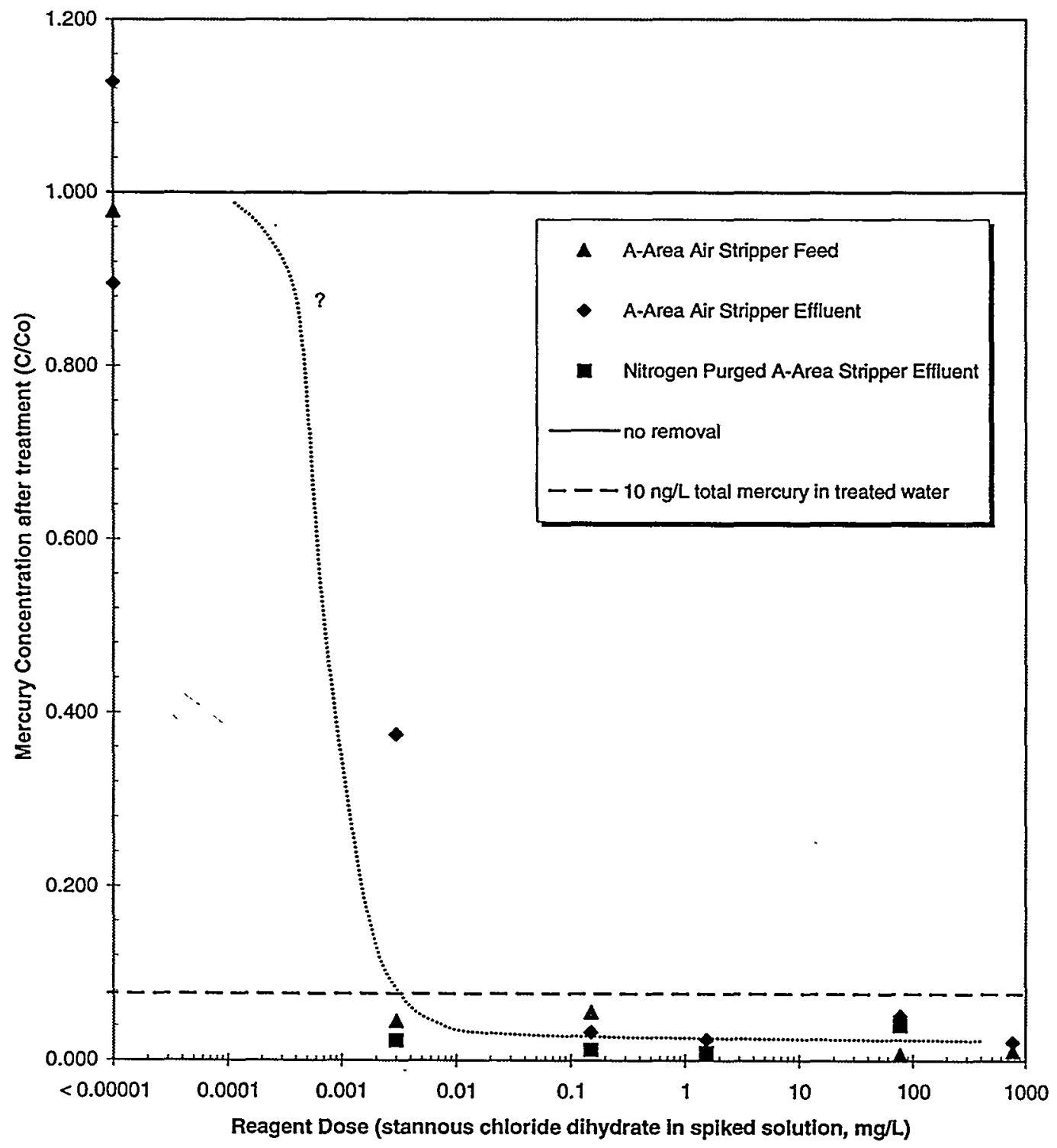

Figure 7: Mercury Treatment - Various Runs Performed at the A-Area Stripper at SRS 
In the untreated samples, sparging removed $0 \%$ of the initial mercury, while in the treated samples all of the removals were $>94 \%$, except for the A-Area Stripper effluent treated at the lowest dose which showed a $63 \%$ reduction. The incomplete mercury removal in the A-Area Stripper effluent at the lowest dose suggests that the tested dosages are approaching the lower effective limit. Further, these results suggest that the concentration of organic compounds in A-Area Stripper feed do not adversely impact the mercury treatment process. The results are consistent with the hypothesis that dissolved oxygen concentrations elevated to saturation in the A-Area Stripper compete with mercury for the reductant - dissolved oxygen is present in the stripper feed, but a lower concentrations. A dotted line indicating the general nature of the treatment is shown on Figure 7. This line is labeled with a question mark because there is limited data on performance for extremely low doses - the data limitation derives from the high efficiency of the process and the fact that there was little mercury remaining in solution even at the lowest tested doses.

\section{Scoping Analysis}

The data clearly indicate that the process is a viable mercury treatment for waters containing $\mathrm{Hg}(\mathrm{II})$. A scoping calculation for a scenario similar to the A-Area Stripper illustrates the nature of a potential implementation. Specific assumptions for the scenario are the following:

- dose rate of $0.01 \mathrm{mg} / \mathrm{L}$ stannous chloride dihydrate (approximately $3 \mathrm{x}$ the lowest tested dose in this study) will provide effective-continuous-robust mercury removal, and

- flow of $0.8 \mathrm{~m}^{3} / \mathrm{min}$ (approx. $200 \mathrm{gpm}$ ) containing $150 \mathrm{ng} / \mathrm{L}$ total mercury as $\mathrm{Hg}$ (II)

For this case, approximately $5 \mathrm{Kg}$ of reagent are needed to treat an entire year of flow. In such a quantity, reagent grade stannous chloride dihydrate costs approximately $\$ 150 / \mathrm{Kg}$ for a yearly reagent cost of less than $\$ 800$. Dosing would need to be performed from a high concentration reagent reservoir using a high precision pump or pressure infusion system. The reservoir requires a nitrogen (or inert gas) headspace for reagent stability. All construction materials up to the infusion point need to be compatible with high concentration stannous chloride solutions - these materials include: CPVC, epoxy, NORYL, teflon, PVDF, Buna N, Kel-F, natural rubber, TYGON, VITON, 316 stainless steel, titanium, glass, and ceramic. Realistic design, capital and installation costs for a good quality dosing system are $\$ 50,000$. Logistics appear reasonable for either dosing option. Reagent can be mixed at $60,000 \mathrm{mg} / \mathrm{L}$ in batches of $20 \mathrm{~L}$ and infused at a rate of approximately $0.15 \mathrm{mU} / \mathrm{min}$. Each batch would last three months (i.e., operators would need to prepare reagent only 4 times per year). Reagent preparation, combined with maintaining logs, periodic adjustments and repairs, should represent less than 0.2 FTE (approximately $\$ 40,000 /$ year). Even if operated for only one year, such a system would cost less than $\$ 0.2 / \mathrm{m}^{3}$ ( $<\$ 1$ per 1000 gallons). These costs assume that an air stripper is in place (such as treating the feed water to the A-Area Stripper). Air stripping/sparging 
costs (these costs are also on the order of $\$ 0.2 / \mathrm{m}^{3}$ or $\$ 1$ per 1000 gallons), if needed, increase the total cost of the proposed process to $<\$ 0.4 / \mathrm{m}^{3}$ ( $<\$ 2$ per 1000 gallons). This cost, conservatively calculated, is significantly less than traditional metals treatment technology costs - especially for target treatment concentrations below $10 \mathrm{ng} / \mathrm{L}$.

\section{Summary and Future Plans}

The scoping stage clearly documented the efficacy of chemical reduction and air stripping/sparging as an ultralow level mercury treatment concept for waters containing $\mathrm{Hg}$ (II). Future work includes confirmation of the results, as well as assembling prototype systems and evaluating practical engineering issues. Planned confirmation steps include repeating the experiment at current and lower doses, additional measurements of related matrix chemistry, and reporting the results of the kinetic study. Planned engineering tests include evaluating the robustness of alternative dosing systems (pumps versus pressure infusion) and evaluating reagent stability over extended periods of time.

\section{References}

Denham, M., B. Looney, J. Koch II, D. Jackson, W. Fulmer, R. Roseberry, J. Noonkester, 1999. SRS Background Mercury Study: Preliminary Summary of Ultra-Low Level Analytical Data, SRT-EST-99-0322, Westinghouse Savannah River Company, Aiken SC 29808.

Looney, B. B., 2000. Laboratory Notebook: Ultralow Level Mercury Treatment Using Chemical Reduction and Air Stripping, WSRC-NB-2000-00028, Westinghouse Savannah River Company, Aiken SC 29808.

Vangelas, K. M. (2000). Task Technical Plan for Ultralow Level Mercury Treatment Using Chemical Reduction and Air Stripping, WSRC-TR-2000-00040, Westinghouse Savannah River Company, Aiken SC 29808. 
WSRC-RP-2000-00697

Rev. 0

Page 15 of 20

\section{APPENDIX 1 - DOSING PROTOCOLS}

Example Dosing Protocol and Calculations

stannous chloride concentration in stock solutlon for 1631

stannous chlorlde concentration in 1631 sample purge container
8.86E-01 M or

4.41E-03 M or
$200000 \mathrm{mg} /$ as stannous chioride dihydrate

$995 \mathrm{mg} / \mathrm{L}$ as stannous chloride dihydrate

mercury molarity at various target concentrations

$\mathrm{Hg}$ concentration

(mgl)

$\mathrm{Hg}$ concentration $\mathrm{Hg}$

(ngll)

Molarity

0.0001
0.001

0.001
0.01

Hg concentration (ug/L)

0.1
1

1

$100 \quad 4.99 E-10$

$1000 \quad 4.99 E-09$

$10000 \quad 4.99 E-08$

Proposed reagent dosing for treatment efficacy study

assumed sample volume

method 1631stock solution (A)

assumed secondary stock solution (B)

assumed tortiary stock (C)

$260 \mathrm{~mL}$

$200000 \mathrm{mg} / \mathrm{h}$ as stannous chloride dinydrate

$400 \mathrm{mg} / \mathrm{L}$ as stannous chloride dihydrate

$0.8 \mathrm{mg} / \mathrm{h}$ as stannous chloride dihydrate

all sparges are assumed to be 30 minutes at $300 \mathrm{~mL} / \mathrm{min}$ (air:water ratio of 34.6 )

stock solution $B=0.1 \mathrm{~mL}$ of stock $A$ brought to $50 \mathrm{~mL}$ with reagent water stock solution $C=0.1 \mathrm{~mL}$ of stock $B$ brought $1050 \mathrm{~mL}$ with reagent water requires $0.1 \mathrm{~mL}$ pipette and tips and $50 \mathrm{~mL}$ graduate $/$ bottle

requires $0.1 \mathrm{~mL}$ pipelte and tips and $50 \mathrm{~mL}$ graduate / bottle

$\begin{array}{ll}\text { blank a } & \text { reagent water } \\ \text { blank b } & \text { reagent water sparged with no stock }\end{array}$

raw water sample (no treatment or sparge)

for each dose, bubbler contains sample plus listed stock addition

dose $0 \quad 0.00 \mathrm{~mL}$ of stock $\quad 0.000001$

dose $1 \quad 1.00 \mathrm{~mL}$ of stock C $\quad 0.003065$

dose $2 \quad 0.10 \mathrm{~mL}$ of stock $B \quad 0.15$

dose $3 \quad 1.00 \mathrm{~mL}$ of stock B

dose $4 \quad 0.10 \mathrm{~mL}$ of stock $A \quad 76.6$

dose $5 \quad 1.00 \mathrm{~mL}$ of stock $A$

$\mathrm{mgl}$ as stannous chloride dihydrate $\mathrm{mgh}$ as stannous chloride dihydrate $\mathrm{mgl}$ as stannous chloride dihydrate $\mathrm{mg} /$ as stannous chloride dihydrate $m g l$ as stannous chloride dihydrate $\mathrm{mg} / \mathrm{L}$ as stannous chloride dihydrate requires $1 \mathrm{~mL}$ pipette and tips

requires $0.1 \mathrm{~mL}$ pipette and tips

requires $1 \mathrm{~mL}$ pipette and tips

requires $0.1 \mathrm{~mL}$ pipette and tips 
WSRC-RP-2000-00697

Rev. 0

Page 16 of 20

(Blank) 
WSRC-RP-2000-00697

Rev. 0

Page 17 of 20

\section{APPENDIX 2 - TABULATED ANALYTICAL RESULTS}


DOSE VS. MERCURY DATA FOR FIELD EXPERIMENT

\begin{tabular}{|c|c|c|c|c|c|}
\hline Sample No. & & $\begin{array}{c}\text { Dose } \\
\text { Protocol }\end{array}$ & $\begin{array}{c}\text { Dose of } \\
\text { stannous } \\
\text { chloride } \\
\text { dihydrate } \\
\text { (mg/L) }\end{array}$ & $\begin{array}{c}\text { Final Hg } \\
(n g / L)\end{array}$ & $\mathrm{ClCO}$ \\
\hline SRDHG 01 & & 0 & 0 & 146.9 & 1.128 \\
\hline SRDHG 02 & & 0 & 0 & 116.5 & 0.894 \\
\hline SRDHG 03 & & $1 \mathrm{ml} \mathrm{A}$ & 766 & 2.83 & 0.022 \\
\hline SRDHG 04 & & $0.1 \mathrm{ml} \mathrm{A}$ & 76.6 & 6.72 & 0.052 \\
\hline SRDHG 05 & & $1 \mathrm{mlB}$ & 1.54 & 3.18 & 0.024 \\
\hline SRDHG 06 & & $0.1 \mathrm{mlB}$ & 0.15 & 4.26 & 0.033 \\
\hline SRDHG 07 & & $1 \mathrm{mlC}$ & 0.003 & 48.83 & 0.375 \\
\hline & & & & & \\
\hline SRDHG 10 & & 0 & 0 & 127.4 & 0.978 \\
\hline SRDHG 13 & & $1 \mathrm{mlA}$ & 766 & 1.47 & 0.011 \\
\hline SRDHG 14 & & $0.1 \mathrm{ml} \mathrm{A}$ & 76.6 & 0.89 & 0.007 \\
\hline SRDHG 15 & & $1 \mathrm{mlB}$ & 1.54 & 1.16 & 0.009 \\
\hline SRDHG 16 & & $0.1 \mathrm{mlB}$ & 0.15 & 7.24 & 0.056 \\
\hline SRDHG 17 & & $1 \mathrm{mlC}$ & 0.003 & 5.92 & 0.045 \\
\hline SRDHG 8 & $\mathrm{~N} 2$ & $1 \mathrm{ml} \mathrm{C}$ & 0.003 & 3.03 & 0.023 \\
\hline SRDHG 9 & $\mathrm{~N} 2$ & $0.1 \mathrm{ml} \mathrm{B}$ & 0.15 & 1.67 & 0.013 \\
\hline SRDHG 11 & $\mathrm{~N} 2$ & $1 \mathrm{ml} \mathrm{B}$ & 1.54 & 1.24 & 0.010 \\
\hline SRDHG 12 & $\mathrm{~N} 2$ & $0.1 \mathrm{ml} \mathrm{A}$ & 76.6 & 5.35 & 0.041 \\
\hline & & & & & \\
\hline & & & & & \\
\hline average Co & & & & 130.26667 & \\
\hline
\end{tabular}


Rev. 0

Page 19 of 20

\section{RAW DATA FROM FIELD EXPERIMENT}

\begin{tabular}{|c|c|c|c|c|c|}
\hline \multicolumn{6}{|c|}{ Total Mercury in Water Samples (Westinghouse Savannah River Site) } \\
\hline \multicolumn{6}{|c|}{ analyzed by } \\
\hline \multicolumn{6}{|c|}{ Frontier Geosciences Inc. 414 Pontius North, Suite B Seattle WA 98109} \\
\hline \multicolumn{6}{|c|}{ phone: 206-622-6960 fax: 206-622-6870 e-mail: nicolasb@ frontier.wa.com } \\
\hline 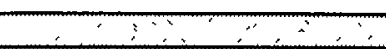 & bottle. & collection. & analysis. & 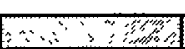 & 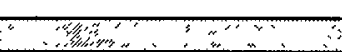 \\
\hline sample ID & number & datén & date & [Hg], ngh & comment : \\
\hline SRDHG-01 & glass & $6 / 21 / 00$ & $6 / 23 / 00$ & 146.90 & \\
\hline SRDHG-02 & glass & $6 / 21 / 00$ & $6 / 23 / 00$ & 116.5 & \\
\hline SRDHG-03 & glass & $6 / 21 / 00$ & $6 / 23 / 00$ & 2.83 & \\
\hline SRDHG-04 & glass & $6 / 21 / 00$ & $6 / 23 / 00$ & 6.72 & \\
\hline SRDHG-05 & glass & $6 / 21 / 00$ & $6 / 23 / 00$ & 3.18 & \\
\hline SRDHG-06 & glass & $6 / 21 / 00$ & $6 / 23 / 00$ & 4.26 & QA Sample \\
\hline SRDHG-07 & glass & $6 / 21 / 00$ & $6 / 23 / 00$ & 48.83 & \\
\hline SRDHG-08 & glass & $6 / 21 / 00$ & $6 / 23 / 00$ & 3.03 & \\
\hline SRDHG-09 & glass & $6 / 21 / 00$ & $6 / 23 / 00$ & 1.67 & \\
\hline SRDHG-10 & glass & $6 / 21 / 00$ & $6 / 23 / 00$ & 127.40 & \\
\hline SRDHG-11 & glass & $6 / 21 / 00$ & $6 / 23 / 00$ & 1.24 & \\
\hline SRDHG-12 & glass & $6 / 21 / 00$ & $6 / 23 / 00$ & 5.35 & \\
\hline SRDHG-13 & glass & $6 / 21 / 00$ & $6 / 23 / 00$ & 1.47 & \\
\hline SRDHG-14 & glass & $6 / 21 / 00$ & $6 / 23 / 00$ & 0.89 & \\
\hline SRDHG-15 & glass & $6 / 21 / 00$ & $6 / 23 / 00$ & 1.16 & \\
\hline SRDHG-16 & glass & $6 / 21 / 00$ & $6 / 23 / 00$ & 7.24 & \\
\hline \multirow[t]{3}{*}{ SRDHG-17 } & glass & $6 / 21 / 00$ & $6 / 23 / 00$ & 5.92 & \\
\hline & & & & & \\
\hline & & & & & \\
\hline blank-1 & & & $6 / 23 / 00$ & 0.12 & \\
\hline blank-2 & & & $6 / 23 / 00$ & 0.1 & \\
\hline blank-3 & & & $6 / 23 / 00$ & 0.13 & \\
\hline mean & & & & 0.12 & \\
\hline \multirow[t]{3}{*}{ SD } & & & & 0.02 & estimated $\mathrm{MDL}=0.04 \mathrm{ng} / \mathrm{L}$ \\
\hline & & & & & \\
\hline & & & & & \\
\hline \multicolumn{6}{|l|}{ repeatability } \\
\hline SRDHG-06 rep 1 & glass & $6 / 21 / 00$ & $6 / 23 / 00$ & 4.45 & \\
\hline SRDHG-06 rep 2 & glass & $6 / 21 / 00$ & $6 / 23 / 00$ & 4.07 & \\
\hline \multirow{2}{*}{ mean } & & & & 4.26 & $8.5 \% \mathrm{RPD}$ \\
\hline & & & & & \\
\hline \multicolumn{6}{|l|}{ standard addition } \\
\hline SADHG-06 $+20.20 \mathrm{ng} / \mathrm{MS}$ & glass & $6 / 21 / 00$ & $6 / 23 / 00$ & 23.29 & $94.2 \%$ recovery \\
\hline SRDHG-06 + $20.20 \mathrm{ng} / \mathrm{L} M S \mathrm{~S}$ & glass & $6 / 21 / 00$ & $6 / 23 / 00$ & 23.38 & $94.7 \%$ recovery \\
\hline \multirow[t]{2}{*}{ mean } & & & & 23.34 & $0.3 \%$ RPD \\
\hline & & & & & \\
\hline & & & & & \\
\hline \multicolumn{6}{|l|}{ certified standard } \\
\hline NIST-1641-d & & & $6 / 23 / 00$ & 7,663 & $96.4 \%$ recovery \\
\hline certified value & & & & 7,950 & \\
\hline
\end{tabular}




\section{BLANKS PERFORMED ON EVERY CLEANED PURGE VESSEL}

\begin{tabular}{|c|c|c|c|c|c|}
\hline \multirow{2}{*}{\multicolumn{6}{|c|}{$\frac{\text { Total Mercury in Purge Vessel Blanks (West }}{\text { analyzed by }}$}} \\
\hline & & & & & \\
\hline \multirow{2}{*}{\multicolumn{6}{|c|}{$\begin{array}{l}\text { Frontier Geosciences Inc. 414 Pontius North, Suite B Seattle WA } 98109 \\
\text { phone: } 206-622-6960 \text { fax: 206-622-6870 e-mail: nicolasb @ frontier.wa.com }\end{array}$}} \\
\hline & & & & & \\
\hline \multicolumn{6}{|c|}{ 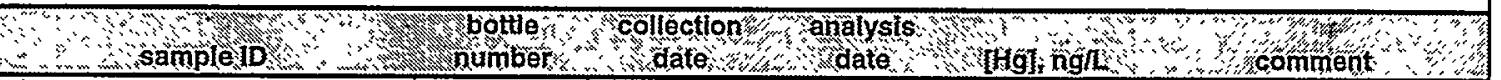 } \\
\hline field purge vessel blank test \#1 & glass & $n / a$ & $3 / 9 / 00$ & 0.30 & \\
\hline field purge vessel blank test \#2 & glass & $n / a$ & $3 / 9 / 00$ & 0.35 & \\
\hline field purge vessel blank test \#3 & glass & $\pi / a$ & $3 / 9 / 00$ & 0.27 & \\
\hline field purge vessel blank test \#4 & glass & $n / a$ & $3 / 9 / 00$ & 0.26 & - \\
\hline field purge vessel blank test $\# 5$ & glass & $n / a$ & $3 / 9 / 00$ & 0.29 & \\
\hline field purge vessel blank test \#6 & glass & $\mathrm{n} / \mathrm{a}$ & $3 / 9 / 00$ & 0.17 & \\
\hline field purge vessel blank test \#7 & glass & $\mathrm{n} / \mathrm{a}$ & $3 / 9 / 00$ & 0.47 & \\
\hline field purge vessel blank test \#8 & glass & n/a & $3 / 9 / 00$ & 0.27 & \\
\hline field purge vessel blank test \#9 & glass & $\mathrm{n} / \mathrm{a}$ & $3 / 9 / 00$ & 0.35 & \\
\hline field purge vessel blank test \#10 & glass & $n / a$ & $3 / 9 / 00$ & 0.73 & \\
\hline field purge vessel blank test \#11 & glass & $\mathrm{n} / \mathrm{a}$ & $3 / 9 / 00$ & 0.19 & \\
\hline field purge vessel blank test \#12 & glass & $\mathrm{n} / \mathrm{a}$ & $3 / 9 / 00$ & 0.40 & \\
\hline field purge vessel blank test \#13 & glass & $\mathrm{n} / \mathrm{a}$ & $3 / 9 / 00$ & 0.28 & mean: $0.33 \mathrm{ng} / \mathrm{L}$ \\
\hline field purge vessel blank test \#14 & glass & $\mathrm{n} / \mathrm{a}$ & $3 / 9 / 00$ & 0.36 & SD: $0.14 \mathrm{ng} / \mathrm{L}$ \\
\hline field purge vessel blank test \#15 & glass & $\mathrm{n} / \mathrm{a}$ & $3 / 9 / 00$ & 0.16 & $\mathrm{~N}: 16$ \\
\hline \multirow[t]{2}{*}{ field purge vessel blank test \#16 } & glass & $\mathrm{n} / \mathrm{a}$ & $3 / 9 / 00$ & 0.43 & \\
\hline & & & & & \\
\hline blank-1 & & & $3 / 9 / 00$ & 0.08 & \\
\hline blank-2 & & & $3 / 9 / 00$ & 0.05 & \\
\hline blank-3 & & & $3 / 9 / 00$ & 0.1 & \\
\hline mean & & & & 0.08 & \\
\hline SD & & & & 0.03 & estimated MDL $=0.08 \mathrm{ng} / \mathrm{L}$ \\
\hline & & & & & \\
\hline NIST-1641-d rep 1 & & & $3 / 9 / 00$ & 7,801 & $98.1 \%$ recovery \\
\hline NIST-1641-d rep 2 & & & $3 / 9 / 00$ & 7,728 & $97.2 \%$ recovery \\
\hline certified value & & & & 7,950 & $0.9 \%$ RSD \\
\hline
\end{tabular}

